\title{
Rational use of land resources: regional aspect
}

\author{
Batrbek Kozyrev ${ }^{1}$, Eleonora Tsoraeva, ${ }^{2,}$, Al-Azawi Nagam $^{3}$, Alda Chibirova ${ }^{4}$, and Aslanbek \\ Kozyrev $^{5}$ \\ ${ }^{1}$ St. Petersburg State University of Aerospace Instrumentation, Bolshaya Morskaya str., 67, 190000, \\ St. Petersburg, Russian Federation \\ ${ }^{2}$ I.T. Trubilin Kuban State Agrarian University, Kalinin str., 13, 350044, Krasnodar, Russia \\ ${ }^{3}$ South Ossetian State University named after A.A. Tibilov, Putin str., 8, 100001, Tskhinvali, \\ Republic of South Ossetia \\ ${ }^{4}$ University of Baghdad, College of Agricultural Engineering Sciences, 17635, Jadriya, Baghdad, \\ Iraq \\ ${ }^{5}$ Gorsky State Agrarian University, Kirov str., 37, 362040, Vladikavkaz, Russia
}

\begin{abstract}
The analysis of the use of the land fund of the Krasnodar Territory and the analysis of the rational use of land resources were conducted, using the following coefficients: coefficient of arable land, coefficient of plowing of the territory, and territory development coefficient. The paper discusses the techniques and methods of statistical analysis of the distribution of the land fund by categories of land in the Krasnodar Territory for 2005-2019. Since the area of land by categories changes in dynamics, the indicators of the growth rate, increase, and average values of the series were used. This gives an understanding of how intensively the land areas of the Krasnodar Territory change. The analysis of the use of the land fund of the Krasnodar Territory is necessary in order to determine the possibilities for a more rational and effective use of it, as well as to preserve and improve the quality of the land. Therefore, it is relevant.
\end{abstract}

\section{Introduction}

One of the key and urgent problems of our time is the rational and efficient use of land. This is caused by the fact that there is a deterioration in the condition of agricultural land in most subjects of the Russian Federation - a decrease in fertility, the development of other negative processes leading to the retirement of agricultural land from turnover.

Analysis is one of the most important tools for obtaining information necessary for making management decisions. The analysis allows accumulating relevant experience and making the most balanced and rational decisions, which ultimately determine the success of the management actions and activities, and, consequently, rational use of land.

Rational use of lands implies their use for their intended purpose in compliance with the established requirements and restrictions, as well as taking into account the compliance of the purpose and nature of the use of specific land plots with their properties. This is the use of lands that does not lead to a decrease in their quality. Efficient use of land is use that

\footnotetext{
* Corresponding author: elionora@list.ru
} 
brings economic, social, environmental or other beneficial results. In the annual message of the President to the Federal Assembly, V.V. Putin noted that the issues of improving the use of land resources is a powerful factor in economic and social development and, at the same time, one of the most difficult and historically acute problems in general, and in our country in particular [1]. Consequently, the analysis of land resources in the regions will improve the efficiency of land use by agricultural enterprises in the region.

\section{Materials and methods}

The materials for the study were statistical data of the Department of the Federal Service for State Registration, Cadastre and Cartography for the Krasnodar Territory (Report on the use and state of land in the Krasnodar Territory for 2005, 2010, 2015, 2019, as well as the Report on the availability of land and their distribution by categories, lands and forms of ownership in the Krasnodar Territory for 2005, 2010, 2015, 2019).

Methods of statistical and system analysis were used to accomplish the assigned tasks.

\section{Results}

The area of the Krasnodar Territory is $75,485 \mathrm{~km}^{2}$ and is ranked $42 \mathrm{nd}$ in terms of this indicator among the regions of the Russian Federation. Agricultural lands occupy about $63 \%$ of the total area of the land fund of the region. From 2005 to 2019, the land fund of the Krasnodar Territory has undergone significant changes in certain categories. Analyzing the changes in the land fund of the region for each category of land, the following changes can be observed. So, agricultural land decreased by 68.7 thousand hectares, and in 2019, they amount to 4695.3 thousand hectares. A decrease in the area can be traced in the following categories of lands: lands of specially protected areas - 8.9 thousand hectares, lands of the water fund -12.2 thousand hectares, and reserve lands - 3.7 thousand hectares, respectively. The lands of settlements increased by 78.2 thousand hectares, the lands of industrial and other special purpose also increased by 7.6 thousand hectares, and forest land - by 7.7 thousand hectares. Figure 1 shows the dynamics of changes in the areas of the land fund of the Krasnodar Territory by land category from 2005 to 2019 [2].

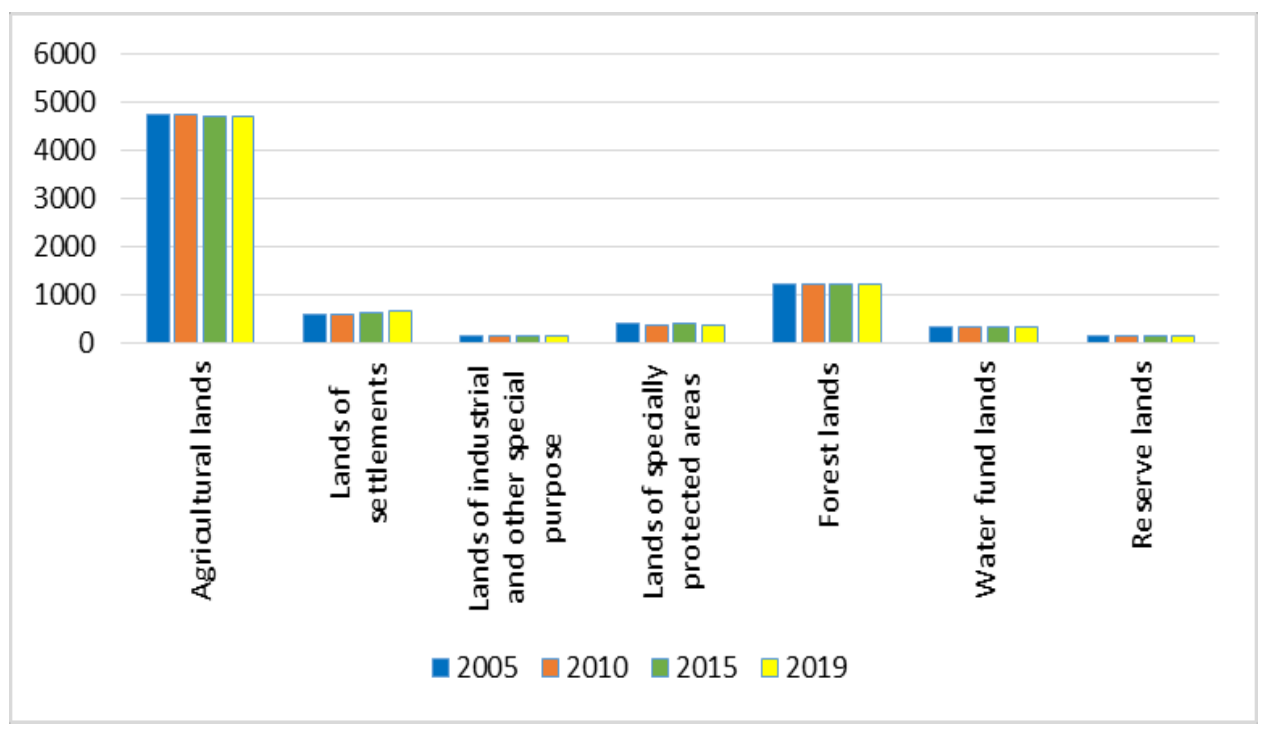

Fig. 1. Distribution of the land fund of the Krasnodar Territory by category, thousand ha. 
In 2019, the lands of settlements occupy $8.6 \%$; lands for industry, transport, communications, radio broadcasting, television, informatics, space support, defense and other purposes $-1.9 \%$; lands of specially protected natural areas - $5 \%$; forest land $-16.0 \%$; water fund lands - 325.1 thousand hectares (4.3\%); reserve lands - 141.6 thousand hectares $(1.9 \%)$.

\section{Discussion}

The area of agricultural land changes from year to year. Dynamics of changes in the area of land of this category for the period 2005-2019 is shown in Figure 2.

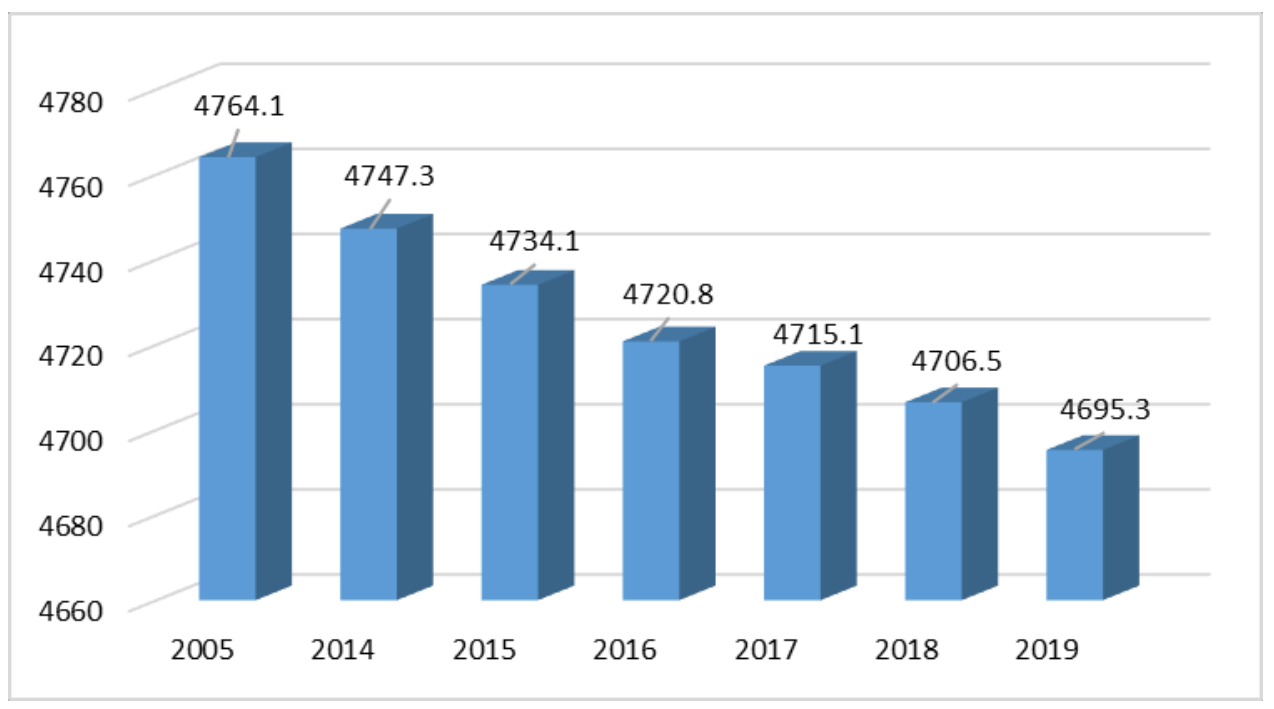

Fig. 2. Dynamics of change in the area of agricultural land in the Krasnodar Territory (2005-2019), ha.

Figure 2 illustrates the linear decline in agricultural land area from 2005 to 2019.

Analysis of the data of state statistical reports shows that in 2019 , the redistribution of the areas of all categories of land continued, which is associated with the land transformations carried out in the region aimed at strengthening various forms of ownership and the development of multi-structure methods of land management, as well as bringing land categories in line with forest, water and land legislation [3].

In Table 1, the absolute increase shows how much the area indicator has changed in relation to the base year - 2005. A negative change in relation to 2005 is observed every year, but the greatest value is the ratio of 2019 to 2005 .

However, the chain absolute growth shows the maximum value of the difference between 2014 and 2005 indicators. The smallest indicator is the ratio of 2017 to $2016--5.7$ ha. On average, by the beginning of 2020, the area of agricultural land has decreased by almost 55 hectares, compared to 2005. 
Table 1. Analysis of the dynamics of changes in the area of agricultural land in the Krasnodar Territory for the period 2005-2019.

\begin{tabular}{|c|c|c|c|c|c|c|c|c|}
\hline \multirow{2}{*}{ Year } & \multirow{2}{*}{$\begin{array}{c}\text { Agricultural } \\
\text { land area, } \\
\text { ha }\end{array}$} & \multicolumn{2}{|c|}{ Absolute growth } & \multicolumn{2}{|c|}{ Growth rate, \% } & \multicolumn{2}{|c|}{$\begin{array}{c}\text { Rate of increase, } \\
\%\end{array}$} & \multirow{2}{*}{$\begin{array}{l}\text { Absolute } \\
\text { content } \\
\text { of } 1 \% \\
\text { increase }\end{array}$} \\
\hline & & basic & chain & basic & chain & basic & chain & \\
\hline 2005 & 4764.1 & & & 100 & & & & \\
\hline 2014 & 4747.3 & -16.80 & -16.80 & 99.65 & 99.65 & -0.35 & -0.35 & 47.64 \\
\hline 2015 & 4734.1 & -30.00 & -13.20 & 99.37 & 99.72 & -0.63 & -0.28 & 47.47 \\
\hline 2016 & 4720.8 & -43.30 & -13.30 & 99.09 & 99.72 & -0.91 & -0.28 & 47.34 \\
\hline 2017 & 4715.1 & -49.00 & -5.70 & 98.97 & 99.88 & -1.03 & -0.12 & 47.21 \\
\hline 2018 & 4706.5 & -57.60 & -8.60 & 98.79 & 99.82 & -1.21 & -0.18 & 47.15 \\
\hline 2019 & 4695.3 & -68.8 & -11.2 & 98.55 & 99.76 & -1.45 & -0.24 & 47.06 \\
\hline total & 28387.9 & & -55 & & & & & \\
\hline
\end{tabular}

The growth rate indicator also speaks about the negative dynamics of the indicator change. The rate of increase indicators show the percentage of the increase in the area of agricultural land. As can be seen from the table, rates of increase are negative. The largest negative rate of increase relative to the base year is in 2018. If we consider chain indicators, then the highest value of -0.35 is in 2014 in relation to 2005 , and also in 2015 in relation to 2014 and in 2016 in relation to $2015--0.28$.

Table 2 presents additional indicators for analyzing the dynamics of changes in the area of agricultural land in the Krasnodar Territory.

Table 2. Average values of indicators of the dynamics of changes in the area of agricultural land in the Krasnodar Territory (2005-2019).

\begin{tabular}{|c|c|c|c|}
\hline $\begin{array}{c}\text { Average level of } \\
\text { the area, ha }\end{array}$ & $\begin{array}{c}\text { Average absolute } \\
\text { increase, ha }\end{array}$ & Average growth rate, \% & $\begin{array}{c}\text { Average rate of } \\
\text { increase, \% }\end{array}$ \\
\hline 4726.17 & -9.83 & 84.92 & -0.7971 \\
\hline
\end{tabular}

The movement of land between categories, land users, landowners and owners of land plots really reflects the current policy in the region, which was carried out in accordance with the adopted laws, decrees of the President of the Russian Federation, decrees of the Government of the Russian Federation, as well as laws and decrees of the regional authorities.

Organization of rational and efficient use of each hectare of land is one of the most important components of the socio-economic development of the public economy. The assessment of the rational use of land is based on the calculation of special coefficients and indicators characterizing the degree of use of the entire fund and individual agricultural land, and the state of the land fund is studied by analysing its composition [4-6].

The analysis of the rational use of agricultural land will be carried out using the coefficients of development of the territory, plowing and use of arable land. Arable land is the most valuable part of agricultural land and is a plot of land that is systematically used for the cultivation of agricultural crops [7-9]. 
The coefficient characterizing the degree of use of agricultural land is determined by the formula:

$$
k_{\text {arable land use }}=\frac{S_{\text {arable.land }}}{S_{\text {agric.land }}}
$$

The coefficient of plowing the area is calculated as follows:

$$
k_{\text {plow }}=\frac{S_{\text {rable.land }}+S_{\text {peren.plant }}+S_{\text {farmstead }}}{S_{\text {total }}}
$$

To characterize the degree of development of the territory of an agricultural enterprise, the coefficient of territory development is used:

$$
k_{\text {terr.devel }}=\frac{S_{\text {agric.land }}+S_{\text {peren.plant }}+S_{\text {settlments }}+S_{\text {transport }}}{S_{\text {total }}}
$$

The obtained results are summarized in table 3 .

Table 3. Indicators of rational use of agricultural land in the Krasnodar Territory.

\begin{tabular}{|l|l|}
\hline Indicators & Value \\
\hline Total area of the territory, thousand ha & 7548.5 \\
\hline Agricultural land area, thousand ha & 4199.3 \\
\hline Arable land area, thousand ha & 3718 \\
\hline Sown area, thousand ha & 3699.9 \\
\hline Area of perennial plantations, thousand hectares & 92.2 \\
\hline Farmstead land area, thousand ha & 486.4 \\
\hline Transport area, thousand ha & 46 \\
\hline Coefficient of the agricultural land use & 0.88 \\
\hline Coefficient of plowing the area & 0.57 \\
\hline Territory development coefficient & 0.46 \\
\hline
\end{tabular}

The analysis showed that agricultural land in the Krasnodar Territory was developed by $46 \%$, plowed up by $57 \%$, and used in production by $88 \%$.

The analysis of the composition and structure of land plots determines the possibility of involving unused land in agricultural production. Based on the analysis, it should be noted that measures should be taken to improve the structure of land use and opportunities for expanding the use of arable land, fodder land, and perennial plantations. Unused agricultural land in the Krasnodar Territory must be involved in agricultural turnover [10, $11]$.

\section{Conclusion}

During the analysis of the indicators of land resources, it was revealed that the use of the land fund is carried out intensively in the Krasnodar Territory, the proportion of arable land is high. It is necessary to carry out measures for the rational use of lands, ensuring their preservation, increasing the productivity and fertility of agricultural land, preventing land erosion, pollution and other unwanted resources. 


\section{References}

1. From V.V. Putin's speech to the Federal Assembly of the Russian Federation. Website of the President of the Russian Federation. www.kremlin.ru/

2. Report on the state and use of land in the Krasnodar Territory in 2005, 2014-2019. Federal Service for State Registration, Cadastre and Cartography. Department of the Federal Service for State Registration of Cadastre and Cartography in the Krasnodar Territory. $\quad$ http://www.frskuban.ru/index.php?option=com_content $\&$ view $=$ article $\&$ id $=10813 \&$ Itemid $=287$

3. S.A. Bekuzarova, S.S. Basiev, A.Kh. Kozyrev, T.A. Dulaev, V.I. Buyankin, Ecological significance of winter camelina in biological agricultures. Journal of Pharmaceutical Sciences and Research 10(4) 893-895 (2018)

4. E. Tsoraeva, A. Bekmurzov, S. Kozyrev, A. Khoziev, A. Kozyrev, Environmental issues of agriculture as a consequence of the intensification of the development of agricultural industry. E3S Web of Conferences 215, 02003 (2020)

5. E. Tsoraeva, S. Mezhyan, M. Kataeva, L. Hugaeva, T. Rogova, GIS technologies used in zoning agricultural land for optimizing regional land use. E3S Web of Conferences 224, 03001 (2020)

6. E.N. Tsoraeva, To the question of the economic efficiency of land use in the municipal formation. Omsk Scientific Bulletin. Series: Society. History. Modernity 5(3), 141-146 (2020)

7. S. Ovchinnikova, D. Abornev, M. Kalinichenko, A. Kalinichenko, A. Sekisov, Optimizing the temperature stress for the furnace volume of a fire-tube boiler. Advances in Intelligent Systems and Computing 1259, 601-610 (Springer) https://doi.org/10.1007/978-3-030-57453-6_57

8. S. Ovchinnikova, M. Kalinichenko, N. Markina, E. Schneider, Energy modernization of housing stock. E3S Web of Conferences 157, 06028 (2020) https://doi.org/10.1051/e3sconf/202015706028

9. M. Kalinichenko, I. Stojanov, D. Abornev, S. Ovchinnikova, Optimization of the regeneration of the sodium-cation ion-exchange filter. IOP Conference Series: Materials Science and Engineering. 905 (2020) https://doi.org/10.1088/1757$\underline{899 X / 905 / 1 / 012034}$

10. M.V. Kataeva, Ecological and economic problems of integrated development and development of territories. Life safety 3 207, 51-53 (2018)

11. V.B. Nepoklonov, I.A. Khabarova, D.A. Khabarov, Monitoring and rational use of agricultural land in the Krasnodar Territory. Vestnik of SSUGaT (Siberian State University of Geosystems and Technologies) 23(1),.167-178 (2018) 